\title{
Structure of AMF Community in an Agroforestry System of Coffee and Macauba Palm
}

\author{
Paulo Prates Júnior ${ }^{1 \star(D)}$ \\ Sandro Lucio Silva Moreira ${ }^{2 \star}$ (D) \\ Thuany Cerqueira Jordão ${ }^{1}$ \\ Aristides Osvaldo Ngolo $^{3}$ (D) \\ Bruno Coutinho Moreira ${ }^{4}$ \\ Ricardo Henrique Silva Santos ${ }^{5}$ \\ Raphael Bragança Alves Fernandes ${ }^{2}$ \\ Maria Catarina Megumi Kasuya ${ }^{1}$ (D) \\ ${ }^{1}$ Universidade Federal de Viçosa, Departamento de Microbiologia, Viçosa, MG, Brasil. \\ ${ }^{2}$ Universidade Federal de Viçosa, Departamento de Solos, Viçosa, MG, Brasil. \\ ${ }^{3}$ Centro Nacional de Investigação Científica (CNIC), Luanda, Angola. \\ ${ }^{4}$ Universidade Federal do Vale do São Francisco, Colegiado de Engenharia Agronômica, Petrolina, PE, Brasil. \\ ${ }^{5}$ Universidade Federal de Viçosa, Departamento de Agronomia, Viçosa, MG, Brasil.
}

\begin{abstract}
Coffee crop in Brazil is typically grown as a monoculture. However, we hypothesized that agroforestry system is favorable association for arbuscular mycorrhizal fungi (AMF), affecting its community structure and potentially impacting crop productivity and agroecosystem health. This study evaluated how the microclimate, soil depth, macauba field spacing and distance between coffee plants and palms affect the structure of the AMF community. The structure of the AMF community was influenced by the soil depth, microclimate features, soil moisture, maximum air temperature, and photosynthetically active radiation (PAR). The distance at which coffee-macauba influences ecological diversity indices of AMF, and higher diversity are related to the proximity between plants. AMF diversity (Richness and Shannon) in the agroforestry system exceeded that observed in the full-sun coffee in the 0-20 soil depth layer. Our results showed that the microclimate, soil depth, plant density, and distance between coffee from macauba affected the AMF community structure.
\end{abstract}

Keywords: Arbuscular mycorrhizal fungi, Acrocomia aculeata, Soil Quality, Microclime, Coffea arabica.

\section{INTRODUCTION AND OBJECTIVES}

Coffee plants show a high degree of dependence on arbuscular mycorrhizal fungi (AMF, Glomeromycota), especially in weathered soils with low natural fertility (Siqueira et al., 1998; Cardoso and Kuyper, 2006; Prates Júnior et al., 2020). These fungi are widely found in association with adult coffee plants in the field (Cardoso et al., 2003; Prates Júnior et al., 2019) and have high incidence and species richness in coffee crops (Dobo et al., 2018; Posada et al., 2018).

The AMF carry out key ecological activities for the operation and management of natural and agricultural systems
(Davison et al., 2020; Belay et al., 2020), contributing to plant development, nutrition, and health (Ismail et al. 2013; Giovannini et al., 2020; Jaitieng et al., 2020). The best performance of mycorrhizal plants is related to its higher efficiency in water and nutrient absorption (Andrade et al., 2009; Püschel et al. 2020 ) and to improvements in this association in soil quality (Zhang et al., 2017). These fungi stand out on account of their increased absorption of water and low mobility nutrients in the soil, such as P and Zn (Gianinazzi et al., 2010; Díaz-Ariza et al., 2021) The hyphae network increase the volume of soil explored by the root system of plants, accessing ions located

${ }^{\star}$ Both authors contributed equally to this work. 
far from the root surface (Smith \& Smith, 2011). Thus, the AMF association favors both growth, coffee productivity (Siqueira et al., 1998; Bhattacharya \& Bagyaraj, 2002) and decreased phosphate fertilization (Perea Rojas et al., 2019; Araújo et al., 2020).

Prolonged monocultures, including coffee, decrease diversity and select AMF species that are generally less efficient in promoting the benefits of mycorrhization (Fernandes et al., 2016; Prates Júnior et al., 2019), interfering in the structure of the AMF community. However, intercropping with other species in agroforestry systems can improve coffee production and stimulates the AMF community, increasing the potential for inoculum in the cultivated and neighboring areas (Muleta et al., 2008; Sánchez et al., 2009; Arias et al., 2012; Prates Júnior et al., 2020).

The choice of the tree component in the coffee to be used in the agroforestry with coffee plays an important role. Tree species and density may affect coffee crop growth and yield, due to microclimate, including availability of water and photosynthetically active radiation (Jaramillo-Botero et al., 2010; Santos et al., 2012) and the microbial community (Veloso et al., 2020; Mukhtar et al., 2021). The use of palm trees (Arecaceae) can be an interesting strategy, given the monopodial canopy architecture, which facilitates partial blocking of solar radiation, and at the same time, allows the passage of sufficient radiation to maintain coffee productivity and farming incomes. The use of macauba (Acrocomia aculeata (Jacq.) Lodd. Ex Mart.) in agroforestry system has been highlighted in the literature (Dias et al., 2011; Viana et al., 2011; Moreira et al., 2018). This is a native palm from tropical regions in the American continent (Dransfield et al., 2008), which produces rich oils from fruit, and can be used in the biodiesel industry (Dias et al., 2011) and in biokerosene for aviation (Boeing et al., 2013), as well exhibit recognized potential for use in land reclamation (Mota et al., 2011) and in carbon credits projects (Moreira et al., 2020).

The most diversified management of coffee plants in agroforestry systems and native forests increases the diversity of AMF (Dobo et al., 2018; Prates Júnior et al., 2019; Belay et al., 2020). This is related, among others, to the AMF enhancing the soil physical-chemical and biological properties, with better exploitation of ecological interactions. The agroforestry system of coffee with macauba results in significant improvements in the edaphoclimatic conditions, including reductions in maximum air temperature and photosynthetic active radiation, culminating in gains in coffee productivity (Moreira et al, 2018). In addition, the root system of macauba palm is extensive, reaching more than one meter in depth and occupies all the area under the palm canopy projection (Moreira et al., 2019), which favors the storage of soil organic carbon.

It has been recognized that agroforestry coffee systems have a higher number of spores in the deep layers of the soil, due to the greater abundance of roots in these layers (Cardoso et al., 2003; Muleta et al., 2008; Arias et al., 2012), shading (Aldrich-Wolfe et al. 2020) and temperature (Davison et al., 2021) are environmental factors of great influence in the AMF community. However, there is little information about the influence of distance, plant density and soil layers on the microclimate and soil physical-chemical factors of the soil and AMF community. In this context, we tested the hypothesis that the density, microclimate, soil depth and distance between coffee and macauba palm affect AMF community structure.

\section{MATERIALS AND METHODS}

\subsection{Site location}

The study was carried out in the Viçosa, located in the Atlantic Rainforest Brazilian biome, in Minas Gerais State, Brazil. The GPS coordinates of the location are $20^{\circ} 45^{\prime} 24.7^{\prime \prime} \mathrm{S}$ and $42^{\circ} 50^{\prime} 33.5^{\prime \prime} \mathrm{W}$, at an altitude of $675 \mathrm{~m}$. The annual average temperature is $19^{\circ} \mathrm{C}$, with an average annual precipitation of $1,340 \mathrm{~mm}$. The experiment was carried out in a clayed Red Yellow Latosol (Hapludox), with a $17 \%$ slope and northwest facing the sun and its radiation (Moreira et al., 2018).

In the area, arabica coffee plants (Coffea arabica cv. Oeiras) are full-sun cropped and in agroforestry system with macauba palm (Acrocomia aculeata) at $2.80 \times 0.75,(4,762$ plants $\left.\mathrm{ha}^{-1}\right)$. Macauba palms are grown with a high $(11.20 \mathrm{x}$ $2.80 \mathrm{~m}, 318$ trees ha $\left.^{-1}\right)$ or low $\left(11.20 \times 4.40 \mathrm{~m}, 203\right.$ trees ha- $\left.{ }^{-1}\right)$ row density (Figure 1).

Aiming to evaluate the edaphoclimatic data and coffee productivity, the experimental area was divided into five treatments: full-sun coffee - control (C), coffee in agroforestry system with macauba palm planted at $1.4 \mathrm{~m}$ (HL1) and $4.2 \mathrm{~m}$ (HL2) distant from high-density macauba palms, and $1.4 \mathrm{~m}$ (LL1) and $4.2 \mathrm{~m}$ (LL2) distant from low-density macauba palms (Figure 1). 




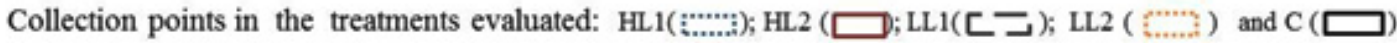

\section{Wacaubas - Coffee trees}

Figure 1. Sketch of the experimental area, indicating the treatments, with macauba with high (H) and, low density (L) and coffee near (L1) or distant (L2) from macauba and in full-sun (control = C).

\subsection{History of the experimental area}

The planting stage of the experiment was in November 2007, and the entire area received the same management until 2014 when the study was carried out. Coffee plants received annual mineral fertilization according to official recommendations for the crop in Minas Gerais State (Ribeiro et al., 1999), distributed in three applications during the rainy season. Fertilizer doses were applied to the coffee crop corresponding to $100 \mathrm{~g}$ (2013) and $150 \mathrm{~g}$ (2014) of 20-5-20 $\left(\mathrm{N}-\mathrm{P}_{2} \mathrm{O}_{5}-\mathrm{K}_{2} \mathrm{O}\right)$ per plant and application. Mechanical control of spontaneous plants was carried out periodically in all treatments, and the residues were left on the soil.

\subsection{Soil temperature and moisture assessment}

Soil temperature and moisture were monitored in 2014 , coinciding with the dry season characterized by low rainfall rates and temperatures in the southeast region of Brazil.

Soil moisture and temperature were monitored using sensors (Decagon ${ }^{\bullet}$ Em50) installed in the center of two soil layers $(0-20$ and $20-40 \mathrm{~cm})$ in the coffee row of all treatments. The sensors were coupled with a data logger (Decagon ${ }^{\circ}$ ECH2O Logger) with data collection scheduled for every $60 \mathrm{~min}$. Moisture sensors used were previously calibrated in the laboratory using soil samples collected in the same areas by the thermogravimetric method.

\subsection{Chemical soil characterization}

Soil samples were collected from the layers at depths of $0-20$ and $20-40 \mathrm{~cm}$ in triplicate to form a composite sample in each treatment, near the location points of the soil temperature and moisture sensors across the coffee rows and sent for chemical routine analysis (Table 1). 
Table 1. Soil chemical characterization from agroforestry system coffee with macauba planted in high (H) and low (L) densities, close (L1) and distant (L2) from the palms, and from full-sun cultivated coffee (control = C).

\begin{tabular}{|c|c|c|c|c|c|c|c|c|c|c|c|c|c|c|}
\hline & $\begin{array}{c}\mathrm{pH} \\
(\mathrm{H} 2 \mathrm{O})\end{array}$ & $\mathbf{P}$ & $\mathbf{K}$ & $\mathrm{Ca}^{2+}$ & $\mathbf{M g}^{2+}$ & $\mathbf{A l ^ { 3 + }}$ & $\mathbf{H}+\mathbf{A l}$ & SB & $\begin{array}{c}\text { CEC } \\
(\mathbf{t})\end{array}$ & $\begin{array}{c}\text { CEC } \\
(\mathrm{T})\end{array}$ & V & m & $\mathbf{O M}$ & P-rem \\
\hline & & \multicolumn{2}{|c|}{$\mathrm{mg} \mathrm{dm}^{-3}$} & \multicolumn{7}{|c|}{$\mathrm{cmol}_{\mathrm{c}} \mathrm{dm}^{-3}$} & \multicolumn{2}{|c|}{$\%$} & dag/kg & $\mathrm{mg} / \mathrm{L}$ \\
\hline Treat & \multicolumn{14}{|c|}{$0-20 \mathrm{~cm}$} \\
\hline $\mathrm{C}$ & 4.65 & 1.10 & 85.00 & 0.74 & 0.35 & 0.49 & 4.20 & 1.31 & 1.80 & 5.51 & 23.80 & 27.20 & 1.39 & 22.40 \\
\hline HL1 & 4.75 & 2.30 & 47.00 & 2.76 & 0.73 & 0.10 & 5.20 & 3.61 & 3.71 & 8.81 & 41.00 & 2.70 & 2.41 & 26.90 \\
\hline HL2 & 5.79 & 1.30 & 142.50 & 2.32 & 0.76 & 0.00 & 4.10 & 3.44 & 3.44 & 7.54 & 45.70 & 0.00 & 1.71 & 26.15 \\
\hline LL1 & 5.28 & 1.50 & 55.00 & 2.35 & 0.79 & 0.10 & 3.70 & 3.28 & 3.38 & 6.98 & 47.00 & 3.00 & 1.90 & 26.80 \\
\hline LL2 & 5.39 & 1.40 & 146.50 & 2.11 & 0.64 & 0.15 & 4.70 & 3.07 & 3.22 & 7.77 & 39.30 & 5.00 & 2.16 & 26.60 \\
\hline \multicolumn{15}{|c|}{$20-40 \mathrm{~cm}$} \\
\hline $\mathrm{C}$ & 5.19 & 0.50 & 21.00 & 0.69 & 0.31 & 0.39 & 3.20 & 1.05 & 1.44 & 4.25 & 24.70 & 27.10 & 1.14 & 27.70 \\
\hline HL1 & 5.60 & 0.90 & 31.00 & 2.12 & 0.59 & 0.00 & 3.70 & 2.79 & 2.79 & 6.49 & 43.00 & 0.00 & 1.65 & 26.20 \\
\hline HL2 & 5.73 & 0.95 & 35.00 & 1.83 & 0.55 & 0.00 & 2.70 & 2.47 & 2.47 & 5.17 & 47.75 & 0.00 & 1.20 & 21.20 \\
\hline LL1 & 5.75 & 1.00 & 45.00 & 1.96 & 0.63 & 0.00 & 3.90 & 2.71 & 2.71 & 6.61 & 41.00 & 0.00 & 1.39 & 27.30 \\
\hline LL2 & 5.64 & 0.45 & 32.00 & 1.49 & 0.53 & 0.05 & 2.35 & 2.10 & 2.15 & 4.45 & 47.15 & 2.55 & 0.83 & 24.05 \\
\hline
\end{tabular}

pH in water-ratio of 1:2.5; $\mathrm{P}$ and K using Mehlich-1 extractor; $\mathrm{Ca}^{2+} \mathrm{Mg}^{2+} \mathrm{Al}^{3+}$ with $\mathrm{KCl} 1 \mathrm{~mol} / \mathrm{L} ; \mathrm{H}+\mathrm{Al}$ with calcium acetate $0.5 \mathrm{~mol} / \mathrm{L}, \mathrm{pH} 7.0 ; \mathrm{SB}=$ sum of bases; $\mathrm{CEC}=\mathrm{cation}$ exchange capability at original $\mathrm{pH}(\mathrm{t})$ and at $\mathrm{pH} 7.0(\mathrm{~T}) ; \mathrm{V}=$ base saturation; $\mathrm{m}=$ aluminum saturation; $\mathrm{OM}=$ organic matter $($ Org. $\mathrm{C}$ x 1.724), Walkley-Black method; $\mathrm{P}$-rem. = remain $\mathrm{P}$.

\subsection{Microclimate characterization}

The minimum and maximum air temperature in the coffee canopy were monitored by chapel-type thermometers. Thermometers were installed inside the coffee canopy at a height of $1.5 \mathrm{~m}$ above the soil surface to avoid direct sunlight. Readings were taken daily in the afternoon $(16: 30 \mathrm{~h})$.

The percentage of shading was obtained through hemispherical photos (Schleppi et al., 2007), which were taken at five points in each treatment in the coffee plant rows. A Canon T2 $\mathrm{i}$ 18-megapixel camera and a "fisheye" lens, mounted on a bubble level tripod, were used, with the images taken at $1.5 \mathrm{~m}$ above the soil surface with the camera pointing in a northward direction. The images were taken before sunrise and under diffuse light exposure, with the aim of obtaining the maximum possible contrast between the leaves and the sky (Whitford et al., 1995). Next, the photos were computer-processed using the GLS (Gap Light Analyzer 2.0) software program to estimate the average percentage of shading in each treatment.

The photosynthetically active radiation (PAR) was evaluated above the coffee canopy using an AccuPar Ceptometer . Readings were taken in triplicate in each treatment.

\subsection{AMF sampling and molecular analysis}

Three composite soil samples (each composed of four subsamples) from the coffee rows of all treatments were collected at a depths of $0-20$ and $20-40 \mathrm{~cm}$ near the humidity and temperature sensors do solo and processed to AMF spore extraction using the wet sifting technique (Gerdemann \& Nicolson, 1963). The total DNA of the AMF community was extracted with the Power Soil DNA kit, MoBio (MoBio Laboratories Carslbad, CA, USA) according to the manufacturer's guidelines and minor adaptations in protocol steps (Prates Júnior et al., 2019). The PCR analysis used the GoTaq ${ }^{\circledR}$ Flex DNA Polymerase enzyme (Promega, Madison, USA) in $50 \mu \mathrm{L}$ of buffer ( $20 \mathrm{mM}$ Tris-HCl; $50 \mathrm{mM} \mathrm{KCl}$; $\mathrm{pH}$ 8.4). The samples consisted of $3 \mu \mathrm{L}$ of the DNA with $200 \mu \mathrm{M}$ of the four triphosphate deoxynucleosides; $1.5 \mathrm{mM} \mathrm{MgCl} ; 0.2 \mu \mathrm{M}$ of each primer; $1.25 \mathrm{U}$ of the GoTaq Flex DNA polymerase enzyme and $0.8 \mu \mathrm{L}\left(0.8 \mu \mathrm{g} \mu \mathrm{L}^{-1}\right)$ of acetylated bovine albumin (BSA, Promega). The first amplification corresponded to the $18 \mathrm{~S}$ rDNA of AMF, with the AM1 primers (5'- GTTTCCCGTAAGGCGCCGAA 3) (Helgason et al., 1998) combined with the universal primer for eukaryotes NS31 (5'-TTGGGGGCAAGTCT - 3') with 580 bp fragments (Simon et al., 1992).

The PCR analysis was run in a thermocycler (Mastercycle epgradient, Eppendorf): i) a first cycle of $1 \mathrm{~min}$ at $94^{\circ} \mathrm{C}, 1 \mathrm{~min}$ at $66^{\circ} \mathrm{C}$ and $1.5 \mathrm{~min}$ at $72{ }^{\circ} \mathrm{C}$; ii) 30 cycles of $30 \mathrm{~s}$ at $94{ }^{\circ} \mathrm{C}$, $1 \mathrm{~min}$ at $66^{\circ} \mathrm{C}$ and $30 \mathrm{~s}$ at $72{ }^{\circ} \mathrm{C}$, and iii) a final extension period of $10 \mathrm{~min}$ at $72^{\circ} \mathrm{C}$. The products of the PCR reactions were submitted to electrophoresis in $0.8 \%$ agarose gel (p:v), stained with ethidium bromide and visualized under UV light in the Molecular Imaging photo documentation (Loccus Biotecnologic L-Pix Chemi). The second amplification (Nested PCR) used a $1 \mu \mathrm{L}$ aliquot of the reaction product of the first PCR, with the NS31-GC primers (5'GGGGCGCGCCCCGGG CGGGGCGGGGGCACGGGGGTTGGAGGGA GTCTGGTGCC-3') (Kowalchuk et al., 2002) and Glo1 (5'GCCTGCTTTAAACACTCTA-3') (Cornejo et al., 2004), the same mixture as described for the first PCR reaction.

The amplifications were generated in a thermocycler in the following steps: i) initial DNA denaturation for $5 \mathrm{~min}$ at $94^{\circ} \mathrm{C}$; ii) 35 cycles with denaturation for $45 \mathrm{~s}$ at $94^{\circ} \mathrm{C}$, and iii) pairing for $45 \mathrm{~s}$ at $52^{\circ} \mathrm{C}$ and extension for $1 \mathrm{~min}$ at $72^{\circ} \mathrm{C}$. The 
products were checked by electrophoresis on an agarose gel $(1.5 \% \mathrm{w}: \mathrm{v})$ stained with ethidium bromide and photographed under ultraviolet light. The products obtained from the second amplification were used for DGGE analysis (DCodeTM System Model - BIO-Rad California USA), according to the methodology described by Liang et al. (2008), with minor modifications (Prates Júnior et al., 2019). The images were analyzed using the Bionumerics ${ }^{\oplus}$ program, which allowed for the construction of dendrograms for assessing the similarity between AMF communities in terms of the distance and the pattern of bands corresponding to the AMF 18S rDNA gene, according to the presence or absence of the amplified regions.

\subsection{Evaluation of coffee productivity}

Coffee yield was assessed, evaluating eight coffee plants per treatment obtained from four replicates each one being composed of two plants. After harvesting, fruit production was recorded, and subsamples were dried until reaching moisture between 12 and $13 \%$. These subsamples were processed to obtain productivity in $\mathrm{kg}$ of processed grains per plant.

\subsection{Statistical analysis}

The pattern of similarity and intensity of the bands present in the DGGE gels was evaluated by the Cosine coefficient index, followed by the Unweighted Pair Group Method with Arithmetic Mean (UPGMA) cluster analysis for the construction of dendrograms, with the aid of the Bionumerics 5.1 program. The similarity matrix obtained was used with the soil chemical, thermal and moisture attributes, and microclimate variables in the principal components analysis (PCA) through the Euclidean distance and logarithmic transformation of the data $(\log .(\mathrm{X}+1))$ by the Canoco 4.5 (Biometris) program.

The ecological diversity indices for OTU (operational taxonomic unit) of AMF obtained by the PCR-DGGE was submitted to the Kolmogorov-Smirnov normality test, followed by ANOVA. The Dunnett's test $(\mathrm{p}<0.05)$ was used to compare the means of the macauba shaded treatments relative to the full-sun coffee (C). The mean values inside the shaded areas were compared using Tukey's test $(\mathrm{p}<0.05)$. Coffee yield was analyzed by Tukey's test $(\mathrm{p}<0.05)$. All statistical analyses were carried out using the $\mathrm{R}$ statistical software, version 3.4 (R Core Team, 2017).

\section{RESULTS AND DISCUSSION}

Bands obtained by PCR-DGGE indicated similarity of AMF community among treatments (Figure 2). These findings can be related to the dominant presence of the roots of macaubas, and, mainly, of coffee plants. Superficial layers $(0-40 \mathrm{~cm})$ represent the region with the highest concentration of absorbent coffee roots (Rena \& Guimarães, 2000), while on the adult macauba, more than $80 \%$ of the root system reaches down to a depth of one-meter (Moreira et al., 2019). The presence of AMF in depth $(20-40 \mathrm{~cm})$ may also be related to the fact that some species occupy preferential niches and sporulate in the deeper layers of the soil (Cardoso et al., 2003; Oehl et al., 2005), contributing to the soil biodiversity in intercropped systems (Arias et al., 2012; Dobo et al., 2018; Prates Júnior et al., 2019).



Figure 2. Dendrogram of AMF community obtained by the Cosine coefficient-UPGMA in the bands obtained by PCR-DGGE to evaluate the similarity of agroforestry system of coffee considering coffee planted close to (L1) and distant (L2) from macauba palm plants in high (H) and low $(\mathrm{L})$ density, and with full-sun coffee crop (control = C), in the 0-20 cm and 20-40 cm layers of soil from macauba. $\mathrm{R}=$ repetition. 
The PCA showed differences in the composition of the AMF community in the plots, with $23.1 \%$ of the variance explained by ordination from the first (PC1, 13.6\%) and second (PC2, 9.5 $\%$ ) axis (Figure 3). PCA revealed that microclimate features affect AMF community structure more than soil chemical attributes, mainly soil moisture, photosynthetically active radiation (PAR), and maximum and average air temperature (Figure 3). In our case, the soil chemical attributes do not play a critical role in determining AMF composition because our study site is homogeneous and received the same crop management practices, including fertilization and control of spontaneous herbs. On the other hand, microclimate conditions can influence soil AMF community dynamics. Temperature, shading, light intensity, and wavelength can stimulate or inhibit the formation of AMF spores, mycorrhizal colonization, and taxonomic composition of the AMF community (Heinemeyer \& Fitter, 2004; Konvalinková \& Jansa, 2016; Freire-Cruz, 2016; Aldrich-Wolfe et al., 2020).
Furthermore, temperature acts how an important abiotic environmental and spatial abiotic driver, defining the realized niche space of AMF (Davison et al., 2021).

Agroforestry system of coffee and macauba palm changed the microclimate of the environment and reduced the maximum air temperature and the PAR in the coffee plant canopy (Table 2). These changes can modify the soil water regime (Moreira et al., 2018) and promote physiological changes in the coffee plants, such as an increase in chlorophyll content and leaf water potential (Bonfim et al., 2010). The consequence can be a change in photoassimilate status in the soil, which impacts the AMF community, because the availability of shade, light and temperature has a great influence on the composition of the AMF community (Aldrich-Wolfe et al., 2020; Davison et al., 2021). However, information about the direct effects of microclimate factors on AMF dynamics is scarce (Bennett \& Classen, 2020), since the result depends on the species of plants associated with AMF species.

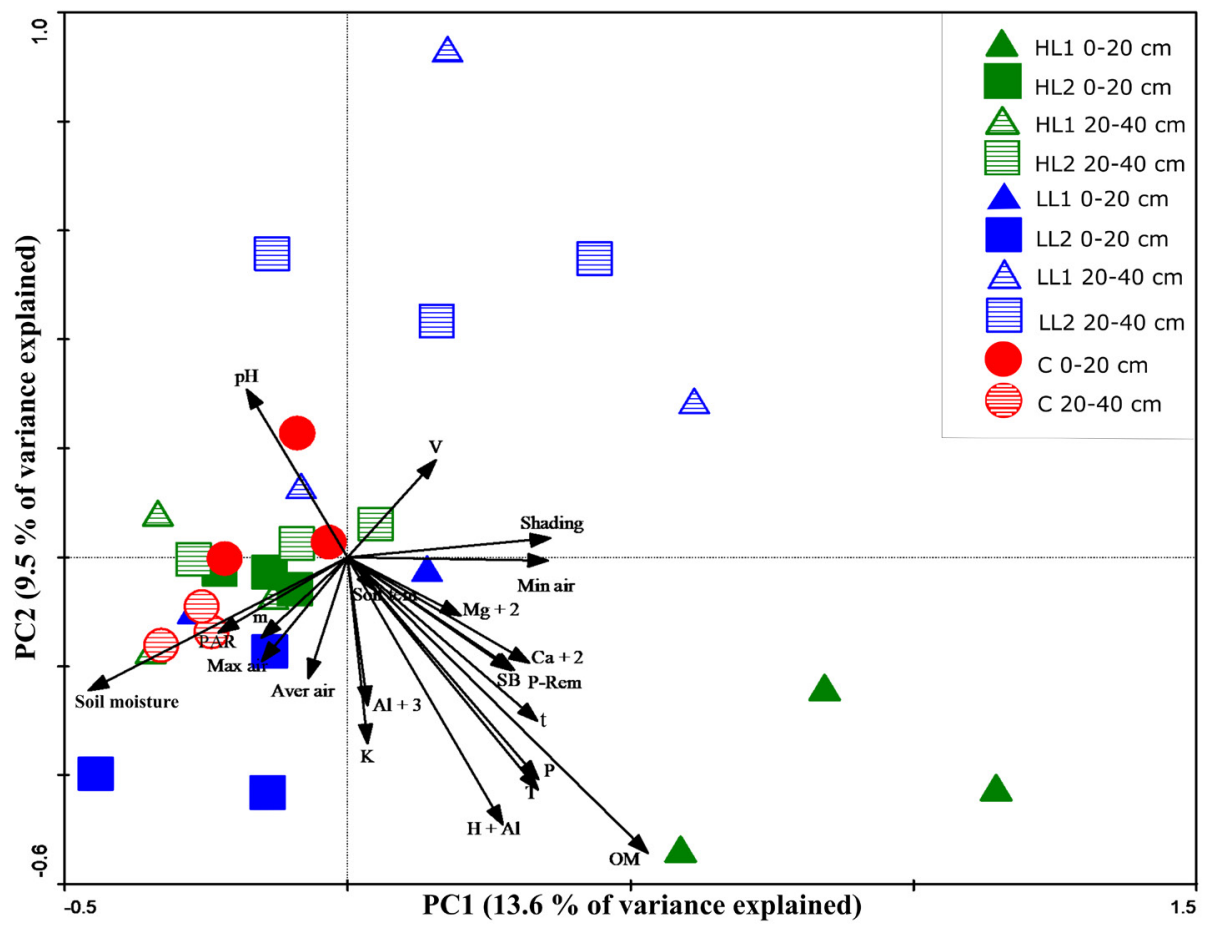

Figure 3. Principal Component Analysis (PCA) based on PCR-DGGE profiles for the AMF community, soil chemical attributes and microclimate variations in agroforestry system of coffee with macauba in high (green), in low (blue) macauba plant densities and in fullsun coffee $($ control $=$ red), in two different soil layers: $0-20 \mathrm{~cm}$ (empty color) and 20-40 cm (cross-line). Distances from coffee plants to macauba represent the close to (L1 - triangle), and far from (L2 - square) distance; and control treatment (circle). SB $=\mathrm{Sum}$ of exchangeable bases; $\mathrm{T}=$ cation exchange capacity at $\mathrm{pH} 7.0 ; \mathrm{t}=$ cation exchange capacity; $\mathrm{V}=$ bases saturation index; $\mathrm{m}=$ aluminum saturation index; $\mathrm{OM}=$ organic matter; P-rem = P-remaining; soil moisture; Soil temp = soil temperature; Max air = maximum air temperature; Min air = minimum air temperature; Aver air = average air temperature; Shading = percentage of shading; PAR = photosynthetically active radiation. 
Table 2. Edaphoclimatic attributes evaluated for coffee agroforestry system with macauba palm in two different soil layers (0-20 and 20-40 cm), in high (H) or low (L) macauba densities, and coffee in full-sun (control = C), and grown close to (L1) and far (L2) from palms.

\begin{tabular}{|c|c|c|c|c|c|c|c|c|c|}
\hline \multirow[b]{2}{*}{ Treatments } & \multicolumn{2}{|c|}{$\begin{array}{l}\text { Soil moisture } \\
\left(\mathrm{m}^{3} \mathrm{~m}^{-3}\right)\end{array}$} & \multicolumn{2}{|c|}{$\begin{array}{c}\text { Soil temperature } \\
\left({ }^{\circ} \mathrm{C}\right)\end{array}$} & \multicolumn{3}{|c|}{$\begin{array}{c}\text { Air temperature } \\
\left({ }^{\circ} \mathrm{C}\right)\end{array}$} & \multirow[t]{2}{*}{$\begin{array}{c}\text { Shading } \\
\%\end{array}$} & \multirow[t]{2}{*}{$\begin{array}{c}\text { PAR } \\
\mu \mathrm{molm}^{-2} \mathrm{~s}^{-1}\end{array}$} \\
\hline & $0-20 \mathrm{~cm}$ & $20-40 \mathrm{~cm}$ & $0-20 \mathrm{~cm}$ & $20-40 \mathrm{~cm}$ & Max & Min & Mean & & \\
\hline C & 0.214 & 0.158 & 17.20 & 18.03 & 31.51 & 9.77 & 20.64 & 2.10 & $1,760.33$ \\
\hline H L1 & 0.159 & 0.153 & 18.27 & 18.93 & 27.02 & 10.36 & 18.69 & 55.90 & 543.33 \\
\hline H L2 & 0.198 & 0.234 & 18.10 & 18.65 & 28.67 & 10.58 & 19.63 & 30.10 & $1,693.00$ \\
\hline L L1 & 0.196 & 0.134 & 18.36 & 18.50 & 26.55 & 10.90 & 18.73 & 57.62 & 439.33 \\
\hline L L2 & 0.219 & 0.186 & 18.38 & 18.64 & 29.65 & 10.94 & 20.30 & 30.10 & $1,724.33$ \\
\hline
\end{tabular}

Soil moisture and temperature were measured using a sensor based on Time Domain Reflectometry (TDR). Data on soil moisture and temperature represent the average value recorded from June to August 2014. Air temperature data refers to the same period. Shading and PAR were evaluated once at the end of August 2014.

Soil chemical characteristics $\left(\mathrm{P}, \mathrm{Ca}^{2+}, \mathrm{Mg}^{2+}, \mathrm{H}+\mathrm{Al}, \mathrm{V}\right.$ e OM, $\mathrm{SB}$, cation exchange capacity) were related to differences in the AMF community in HL1 agroforestry system of coffee and macauba palm at the $0-20 \mathrm{~cm}$ depth. The AMF community of the agroforestry system of coffee grown in LL2 at a depth of 20-40 $\mathrm{cm}$ was less influenced by microclimate features and soil characteristics (Figure 3). The high density of macauba and the position near coffee plants in HL1 may favor higher organic carbon contents due to the root turnover providing nutrients to the AFM community.

Although usually the soil fertility explains variations in species richness and diversity of AMF community in coffee plantations, especially in the surface layer (Siqueira et al., 1998; Posada et al., 2018), our study shows that microclimate attributes can play an important role in the AMF community, with potential impacts on crop productivity as observed by Moreira et al. (2018).

AFM diversity received less influence from the macauba planting density, and the distance of $1.4 \mathrm{~m}$ (HL1) exhibited a higher reading on the Chao richness estimator index than the $4.2 \mathrm{~m}$ (HL2) and the higher indices of richness, Shannon and Chao, than control (C) in the $0-20 \mathrm{~cm}$ soil layer (Table 3 ).

The high density and proximity of coffee and macauba favor AMF diversity (Table 3), probably due to the greater availability of organic matter and nutrients (Figure 3 and Table 1), characteristics which may be the consequence of the higher root concentration and the presence of a milder microclimate (Moreira et al., 2018). Functionally distinct plants such as coffee and macauba can recruit distinct fungal communities because they contribute to functional diversity (Davison et al., 2020). These integration effects were also reported in coffee plantations intercropped with green manure or perennial crops, where the improvements in availability of plant hosts and soil exudates contribute to the increasing number of propagules and AMF diversity (Sánchez et al., 2009; Dobo et al., 2018; Prates Júnior, 2019; Díaz-Ariza et al., 2021).

Table 3. Diversity indexes for OTU of arbuscular mycorrhizal fungi (AMF) obtained by the PCR-DGGE in agroforestry system of coffee and macauba palm, in high $(\mathrm{H})$ or low $(\mathrm{L})$ macauba densities, and coffee in full-sun (control = C), grown close to (L1) and far (L2) from palms.

\begin{tabular}{|c|c|c|c|c|c|}
\hline \multicolumn{6}{|c|}{ Soil depth $(0-20 \mathrm{~cm})$} \\
\hline Treatment & Richness & Dominance & Simpson & Shannon & Chao \\
\hline $\mathrm{C}$ & 2.66 & 0.41 & 0.58 & 0.92 & 5.33 \\
\hline HL1 & $10.00 \mathrm{a}^{\star}$ & 0.10 & 0.90 & $2.30^{\star}$ & $55.00 \mathrm{a}^{\star}$ \\
\hline HL2 & $3.33 \mathrm{~b}$ & 0.36 & 0.63 & 1.06 & $6.33 \mathrm{~b}$ \\
\hline LL1 & $5.33 \mathrm{ab}$ & 0.27 & 0.72 & 1.50 & $21.00 \mathrm{ab}$ \\
\hline LL2 & $6.00 \mathrm{ab}$ & 0.20 & 0.79 & 1.71 & $23.33 \mathrm{ab}$ \\
\hline CV \% (Tukey' test) & 35.96 & 57.21 & 17.38 & 30.11 & 50.85 \\
\hline CV \% (Dunnett's test) & 39.47 & 52.44 & 19.36 & 33.46 & 57.61 \\
\hline \multicolumn{6}{|c|}{ Soil depth $(20-40 \mathrm{~cm})$} \\
\hline Treatment & Richness & Dominance & Simpson & Shannon & Chao \\
\hline $\mathrm{C}$ & 5.33 & 0.25 & 0.74 & 1.50 & 22.33 \\
\hline HL1 & 4.66 & 0.22 & 0.77 & 1.52 & 13.66 \\
\hline HL2 & 5.66 & 0.21 & 0.78 & 1.63 & 22.00 \\
\hline LL1 & 6.66 & 0.16 & 0.83 & 1.84 & 27.66 \\
\hline LL2 & 3.33 & 0.34 & 0.65 & 1.13 & 8.00 \\
\hline CV \% (Tukey' test) & 43.25 & 43.53 & 13.55 & 28.05 & 79.43 \\
\hline CV \% (Dunnett's test) & 53.44 & 48.24 & 15.32 & 33.86 & 97.22 \\
\hline
\end{tabular}

Means followed by the same letter in each column were not different by Tukey's test $(\mathrm{p}<0.05)$ at the same soil depth and for shaded treatments (HL1, HL2, LL1, and LL2). Means followed by an asterisk $\left(^{*}\right)$ were significantly different from the full-sun coffee $(\mathrm{C}=$ control) by Dunnett's test $(\mathrm{p}<0.05)$ at the same soil depth. 
The biennial pattern of coffee production in Brazil was confirmed in our study. In a year characterized by low productivity (2013), the productivity of full-sun coffee (C) was like shaded coffee by macaubas, except for the LL2 treatment, which generated lower productivity compared to the control (Table 4). In the following year of higher production (2014), the shaded coffee grown farthest from macaubas (L2) presented higher productivity compared to the full-sun coffee $(\mathrm{C})$ and the shaded coffee closest to the macaubas (L1). The biennium average productivity (20132014) shows that agroforestry system of coffee and macauba palm improves productivity only if coffee plants are cultivated farthest from the macaubas (L2). This can be related to the microclimate conditions more favorable to the coffee productivity and lower nutrient competition with macauba when the distance is $4.20 \mathrm{~m}$ (L2), which is three times more than in L1. The L2 position was associated with higher soil moisture, air temperature, sun radiation (PAR) and lower shading rates (Table 2). These microclimate conditions are related to improved coffee plant productivity (JaramilloBotero et al., 2010; Santos et al., 2012; Rigal et al., 2020) and the associated microbiota, that includes bacteria, fungi, and the AMF (Steidinger et al., 2019; Aldrich-Wolfe et al., 2020; Rao et al., 2020; Veloso et al., 2020; Mukhtar et al., 2021).

Table 4. Productivity of coffee plants in the agroforestry system with macaubas and in full-sun cultivation (C).

\begin{tabular}{cccc}
\hline \multicolumn{3}{c}{ Coffee yield (kg/plant) } \\
\hline Treatment & 2013 & 2014 & Mean 2013/2014 \\
C & $0.185 \mathrm{a}$ & $0.299 \mathrm{~b}$ & $0.242 \mathrm{c}$ \\
HL1 & $0.178 \mathrm{a}$ & $0.277 \mathrm{~b}$ & $0.228 \mathrm{c}$ \\
HL2 & $0.159 \mathrm{ab}$ & $0.837 \mathrm{a}$ & $0.498 \mathrm{a}$ \\
LL1 & $0.183 \mathrm{a}$ & $0.221 \mathrm{~b}$ & $0.202 \mathrm{c}$ \\
LL2 & $0.087 \mathrm{~b}$ & $0.707 \mathrm{a}$ & $0.397 \mathrm{~b}$ \\
CV $\%$ & 24.01 & 13.63 & 6.88 \\
\hline
\end{tabular}

Coffee plants and macauba palm in high (H) and low (L) planting density and $1.4 \mathrm{~m}$ close to (L1) and $4.2 \mathrm{~m}$ (L2) distant from palms. Means followed by the same letter in each column are not different by Tukey's test $(\mathrm{p}<0.05)$.

The literature relates that AMF can provide early development and yield increases in coffee (Siqueira et al., 1998) because it promotes increases in nutrient absorption and protects plants against several pathogens (Andrade et al., 2009; Ismail et al. 2013; Jaitieng et al., 2020). The same microorganisms improve soil structure and aggregation by extra-radical hyphae and/or glycoprotein exudation (Banks et al., 2011; Zhang et al., 2017). All these benefits are dependent on the ecological context, which includes both microclimatic and edaphic aspects (Aldrich-Wolfe et al., 2020; Cruz et al., 2020; Araújo et al., 2020). In intercropped systems, this concern needs to be considered, to manage the microclimate conditions (Arias et al., 2012; Dobo et al., 2018; Aldrich-Wolfe et al. 2020), as determined by the density planting and distance to the tree, aiming to maintain or reach optimum AMF diversity. Thus, further studies are required to find the best spatially and temporally organization of intercropped systems to balance the benefits of the agroforestry system on coffee and macauba yields with the diversity in AMF.

This study contributes to increasing the understanding of the AMF community distribution in agroforestry system of coffee and macauba palm, supporting decision-making, and aiming at sustainable and productive agricultural practices related to the microclimate and plant spacing variables. In addition to bringing benefits in microclimatic and ecological features shown in the present study, a coffee and macauba combination can provide economic benefits. While coffee is an international and consolidated agricultural commodity (Lewin et al., 2004), macauba is a relatively new crop in farming systems around the world (Motoike et al., 2013), experimenting with an expanding crop area where the fruit is rich in oils that can be used in several industrial sectors. A recent study highlighted the potential of the macauba as regards carbon sequestration (Moreira et al., 2020), and cultured agroforestry systems can mitigate change and maintain areas favorable to coffee production (Gomes et al., 2020), minimizing the effects of climate change and generating potential income from the carbon credits market. The benefits of macaubas on the microclimate can also be relevant to the AMF community because it is not yet understood how these microorganisms respond to global climate change (Bennett \& Classen, 2020). However, it is already recognized that the AMF community responds strongly to shade and temperature gradients (Aldrich-Wolfe et al., 2020; Davison, et al., 2021), which will allow us to manipulate microclimate conditions to favor the multifunctional role of these fungi. The microclimate conditions provided by macaubas can probably minimize the impacts of climate change and favor mycorrhizal symbiosis in productive systems. 


\section{CONCLUSIONS}

The structure of the AMF community in the agroforestry system of coffee and macauba palm is affected by microclimate, soil depth, palm field spacing, and the distance between coffee plants and the macaubas. The highest ecological diversity in this agroforestry system is reached when palms are located closer to the coffee plants.

\section{ACKNOWLEDGEMENTS}

To Conselho Nacional de Desenvolvimento de Científico e Tecnológico (CNPq), Coordenação de Aperfeiçoamento de Pessoal de Nível Superior (CAPES - Código de Financiamento 001) and Fundação de Amparo à Pesquisa de Minas Gerais ( FAPEMIG), for financial support. We wish to thank DSc. Lucas Carvalho Gomes, MSc. Wander Douglas Pereira and MSc. Filipe Fernandes de Sousa for their comments and contributions.

\section{SUBMISSION STATUS}

Received: 01 Mar. 2021

Accepted: 20 Apr. 2021

Associate editor: Eduardo Vinicius da Silva (1)

\section{CORRESPONDENCE}

\section{Maria Catarina Megumi Kasuya}

Universidade Federal de Viçosa, Departamento de Microbiologia, Av. Peter Henry Rolfs s/n, (UFV), 36570- 900, Viçosa, MG e-mail: mkasuya@ufv.br

\section{REFERENCES}

Aldrich-Wolfe L, Black KL, Hartmann EDL, Shivega WG, Schmaltz LC, McGlynn RD et al. Taxonomic shifts in arbuscular mycorrhizal fungal communities with shade and soil nitrogen across conventionally managed and organic coffee agroecosystems. Mycorrhiza 2020; 30(4): 513-527. https://doi:10.1007/s00572-020-00967-7

Andrade SAL, Mazzafera P, Schiavinato MA, Silveira APD. Arbuscular mycorrhizal association in coffee. J Agric Sci. 2009; 147: 105-115. https://doi.org/10.1017/S0021859608008344

Araújo FHV, Cruz RS, Porto DWB, Machado CMM, França AC. Effects of mycorrhizal association and phosphate fertilization on the initial growth of coffee plants. Pesq. Agropec. Trop. 2020; 50: e58646. https://doi.org/10.1590/1983-40632020v5058646

Arias RM, Heredia-Abarca G, Sosa VJ, Fuentes-Ramírez LE. Diversity and abundance of arbuscular mycorrhizal fungi spores under different coffee production systems and in a tropical montane cloud forest patch in Veracruz, Mexico. Agrofor Syst. 2012; 85: 179-193. https://doi.org/10.1007/s10457-011-9414-3

Banks JE, Cline E, Castro S, Urena N, Nichols K, Hannon L, Chandler M. Effects of Synthetic Fertilizer on Coffee Yields and Ecosystem Services: Parasitoids and Soil Glomalin in a Costa Rican Coffee
Agroecosystem. J. Crop. Improv. 2011; 25(6): 650-663. https://doi. org/10.1080/15427528.2011.599919

Belay Z, Negash M, Kaseva J, Vestberg M, Kahiluoto H. Native forests but not agroforestry systems preserve arbuscular mycorrhizal fungal species richness in southern Ethiopia. Mycorrhiza 2020; 30 : 749-759. https://doi.org/10.1007/s00572-020-00984-6

Bennett AE, Classen AT. Climate change influences mycorrhizal fungalplant interactions, but conclusions are limited by geographical study bias. Ecology 2020; e02978. https://doi.org/10.1002/ecy.2978

Bhattacharya S, Bagyaraj DJ. Effectiveness of Arbuscular Mycorrhizal Fungal Isolates on Arabica Coffee (Coffea arabica L.), Biol Agric Hortic. 2002; 20: 125-131. https://doi.org/10.1080/01448765.200 2.9754956

Boeing, Embraer, Fapesp, Unicamp, 2013. Flight path to aviation biofuels in Brazil: action plan, p. 60 [cited 2021 fev. 23]. Available from: http://www.fapesp.br/publicacoes/flightpath-toaviationbiofuels- in-brazil-action-plan.pdf

Bonfim JA, Matsumoto SN, Lima JM, César FRCF, Santos MAF. Fungos micorrízicos arbusculares (FMA) e aspectos fisiológicos em cafeeiros cultivados em sistema agroflorestal e a pleno sol. Bragantia 2010; 69: 201-206. https://doi.org/10.1590/S000687052010000100025

Cardoso IM, Boddington C, Janssen BH, Oenema O, Kuyper W, Kuyper TW. Distribution of mycorrhizal fungal spores in soils under agroforestry and monocultural coffee systems in Brazil. Agrofor Syst. 2003; 58: 33-43. https://doi.org/10.1023/A:1025479017393

Cardoso IM, Kuyper TW. Mycorrhizas and tropical soil fertility. Agric Ecosyst Environ. 2006; 116: 72-84. https://doi.org/10.1016/j. agee.2006.03.011

Cornejo P, Azcó-Aguilar C, Barea JM, Ferrol N. Temporal temperature gradient gel electrophoresis (TTGE) as a tool for the characterization of arbuscular mycorrhizal fungi. FEMS Microbiol Lett. 2004; 241: 265-270. https://doi.org/10.1016/j.femsle.2004.10.030

Cruz RS, Araújo FHV, França AC, Sardinha LT, Machado CMM. Physiological responses of Coffea arabica cultivars in association with arbuscular mycorrhizal fungi. Coffee. Sci. 2020; 15: e151641. https://doi.org/10.25186/cs.v15i.1641

Davison J, de León DG, Zobel M, Moora M, Guilherme Bueno C, Barceló $\mathrm{M}$, et al. Plant functional groups associate with distinct arbuscular mycorrhizal fungal communities. New Phytol. 2020; 226: 1117-1128. https://doi.org/10.1111/nph.16423

Davison J, Moora M, Semchenko M, Adenan SB. et al. Temperature and $\mathrm{pH}$ define the realized niche space of arbuscular mycorrhizal fungi. New Phytol. 2021. https://doi.org/10.1111/nph.17240

Díaz-Ariza LA, Rivera EL, Sánchez N. Occurrence of arbuscular mycorrhizal fungi in leaf litter and roots of shaded coffee plantations under organic and conventional management. Rev Bras Cienc Solo. 2021;45:e0200110. https://doi.org/10.36783/18069657rbcs20200110

Dias HCT, Sato AY, Neto SNO, Morais TC, Freire A, Bento PS. Cultivo da macauba: ganhos ambientais em áreas de pastagens. Inf. Agropecu. 2011; 32:52-60.

Dobo B, Asefa F, Asfaw Z. Effect of tree-enset-coffee based agroforestry practices on arbuscular mycorrhizal fungi (AMF) species 
diversity and spore density. Agrofor Syst. 2018; 92: 525-540. https:// doi.org/10.1007/s10457-016-0042-9

Dransfield J, Uhl NW, Asmussen CB, Baker WJ, Harley MM, Lewis CE. Genera Palmarum: the Evolution and Classification of Palms. Royal Botanic Gardens Richmond, UK, Kew; 2008.

Fernandes RA, Ferreira DA, Saggin-Junior OJ, Stürmer SL, Paulino HB, Siqueira JO, Carneiro MAC. Occurrence and species richness of mycorrhizal fungi in soil under different land use. Can J Soil Sci. 2016; 96: 271-280. https://doi.org/10.1139/cjss-2015-0011

Freire-Cruz A. Effect of light-emitting diodes on arbuscular mycorrhizal fungi associated with bahiagrass (Paspalum notatum Flügge) and millet [Pennisetum glaucum (L.) R. Br]. Bioagro, 2016; 28(3): 163-170.

Gerdemann JW, Nicolson TH. Spores of mycorrhizal Endogone species extracted from soil by wet sieving and decanting. Trans Br Mycol Soc. 1963; 46:235-244. https://doi.org/10.1016/S00071536(63)80079-0

Gianinazzi S, Gollotte A, Binet MN, van Tuinen D, Redecker D, Wipf D. Agroecology: the key role of arbuscular mycorrhizas in ecosystem services. Mycorrhiza. 2010; 20(8): 519-530. https//doi:10.1007/ s00572-010-0333-3

Giovannini L, Palla M, Agnolucci M, Avio L, Sbrana C, Turrini A, Giovannetti M. Arbuscular Mycorrhizal Fungi and Associated Microbiota as Plant Biostimulants: Research Strategies for the Selection of the Best Performing Inocula. Agronomy. 2020; 10, 106. https://doi.org/10.3390/agronomy10010106

Gomes LC., Bianchi FJJA., Cardoso IM., Fernandes RBA., Filho EIF., Schulte RPO. Agroforestry systems can mitigate the impacts of climate change on coffee production: A spatially explicit assessment in Brazil. 2020; 294:106858. https://doi.org/10.1016/j. agee.2020.106858

Heinemeyer A, Fitter AH. Impact of temperature on the arbuscular mycorrhizal (AM) symbiosis: growth responses of the host plant and its AM fungal partner, J Exp Bot. 2004; 55: 525-534. https:// doi.org/10.1093/jxb/erh049

Helgason T, Daniell TJ, Husband R, Fitter AH, Young JP. Ploughing up the wood-wide web? Nature 1998; 394: 431. https://doi. org/10.1038/28764

Ismail Y, McCormick S, Hijri M. The arbuscular mycorrhizal fungus, Glomus irregulare, controls the mycotoxin production of Fusarium sambucinum in the pathogenesis of potato. FEMS. Microbiol. Lett. 2013; 348(1): 46-51. https://doi.org/10.1111/1574-6968.12236

Jaitieng S, Sinma K, Rungcharoenthong P, Amkha S. Arbuscular mycorrhiza fungi applications and rock phosphate fertilizers enhance available phosphorus in soil and promote plant immunity in robusta coffee. Soil Science and Plant Nutrition. 2020; 1-5. https://doi.org /10.1080/00380768.2020.1848343

Jaramillo-Botero C, Santos RHS, Martinez HEP, Cecon PR, Fardin MP. Production and vegetative growth of coffee trees under fertilization and shade levels. Sci. Agric. 2010; 67: 639-645. https:// doi.org/10.1590/S0103-90162010000600004

Konvalinková T, Jansa J. Lights off for arbuscular mycorrhiza: on its symbiotic functioning under light deprivation. Front plant Sci. 2016; 7: 1-11. https://doi.org/10.3389/fpls.2016.00782

Kowalchuk GA, de Souza FA, van Veen JA. Community analysis of arbuscular mycorrhizal fungi associated with Ammophila arenaria in Dutch coastal sand dunes. Mol Ecol. 2002; 11: 571-81. https:// doi.org/10.1046/j.0962-1083.2001.01457.x

Lewin, B., Giovannucci, D., Varangis, P. Coffee Markets: New paradigms in global supply and demand. Agriculture and Rural Development. [cited 2021 fev. 23]. Available from:http:// documents1.worldbank.org/curated/pt/899311468167958765/ pdf/283000REVISED0Coffee1Markets01PUBLIC1.pdf

Liang Z, Drijber RA, Lee DJ, Dwiekat IM, Harris SD, Wedin DA. A DGGE-cloning method to characterize arbuscular mycorrhizal community structure in soil. Soil Biol Biochem. 2008; 40: 956-966. https://doi.org/10.1016/j.soilbio.2007.11.016

Moreira SLS, Imbuzeiro HMA, Dietrich OHS, Henriques E, PereiraFlores ME, Pimentel LD, Fernandes RBA. Root distribution of cultivated macauba trees. Ind Crop Prod. 2019; 137: 646-651. https:// doi.org/10.1016/j.indcrop.2019.05.064

Moreira SLS, Imbuzeiro HMA, Silvert C, Dietrich OHS, Pimentel LD, Fernandes RBA. Above- and below-ground carbon accumulation in cultivated macauba palm and potential to generate carbon credits. J Clean Prod. 2020; 265: 121628. https://doi.org/10.1016/j. jclepro.2020.121628

Moreira SLS, Pires CV, Marcatti GE, Santos RHS, Imbuzeiro HMA, Fernandes RBA. Intercropping of coffee with the palm tree, macauba, can mitigate climate change effects. Agr Forest Meteorol. 2018; 256-257: 379-390. https://doi.org/10.1016/j.agrformet.2018.03.026 Motoike SY, Carvalho M, Pimentel LD, Kuki KN, Paes JMV, Dias HCT, Sato AY. A Cultura da Macauba- implantação e manejo de cultivos racionais. Viçosa, MG. UFV, 2013.

Mukhtar H, Lin C-M, Wunderlich RF, Cheng L-C, Ko M-C, Lin Y-P. Climate and land cover shape the fungal community structure in topsoil. Science of the total environment. 2021; 751: 141721. https://doi.org/10.1016/j.scitotenv.2020.141721

Muleta D, Assefa F, Nemomissa S, Granhall U. Distribution of arbuscular mycorrhizal fungi spores in soils of smallholder agroforestry and monocultural coffee systems in southwestern Ethiopia. Biol Fertil Soils. 2008; 44: 653-659. https://doi.org/10.1007/ s00374-007-0261-3

Oehl F, Sieverding E, Ineichen K, Ris E, Boller T, Wiemken A. Community in extensively soil and intensively different depths managed agroecosystems. New Phytol. 2005; 165: 273-283. https:// doi.org/10.1111/j.1469-8137.2004.01235.x

Perea Rojas Y C, Arias RM, Medel Ortiz R, Aguilar DT, Heredia G, Yon YR. Effects of native arbuscular mycorrhizal and phosphatesolubilizing fungi on coffee plants. Agrofor. Syst. 2019; 93: 961-972. https://doi.org/10.1007/s10457-018-0190-1

Posada RH, Sánchez de Prager M, Heredia-Abarca G, Sieverding E. Effects of soil physical and chemical parameters, and farm management practices on arbuscular mycorrhizal fungi communities and diversities in coffee plantations in Colombia and Mexico. Agroforest Syst. 2018; 92: 555-574. https://doi.org/10.1007/s10457-016-0030-0

Prates Júnior P, Moreira BC, Silva MCS, Veloso TGR, Stürmer SL, Fernandes RBA, Mendonça ES, Kasuya MCM. Agroecological coffee management increases arbuscular mycorrhizal fungi diversity. PlosOne 2019; 8: e0209093. https://doi.org/10.1371/journal. pone.0209093

Prates Júnior P, Veloso TGR, da Silva MCS, da Luz JMR, Oliveira SF, Kasuya MCM. Soil microorganisms and quality of the coffee 
beverage. In: Pereira LL, Moreira TR (eds). Quality Determinants In Coffee Production. Springer Nature. 2020. https://doi. org/10.1007/978-3-030-54437-9_3

Püschel D, Bitterlich M, Rydlová J. et al. Facilitation of plant water uptake by an arbuscular mycorrhizal fungus: a Gordian knot of roots and hyphae. Mycorrhiza 2020; 30:299-313. https://doi.org/10.1007/ s00572-020-00949-9

R Core Team. A Language and Environment for Statistical Computing. 2017. https://www.R-project.org/

Rao MV, Rice RA, Fleischer RC, Muletz-Wolz CR. Soil fungal communities differ between shaded and sun-intensive coffee plantations in El Salvador. PlosOne, 2020; 15(4): e0231875. https:// doi.org/10.1371/journal.pone.0231875

Rena, AB., Guimarães, PTG. Sistema radicular do cafeeiro: estrutura, distribuição, atividade e fatores que o influenciam. EPAMIG, Belo horizonte, pp. 80 (Documento,37), 2000.

Ribeiro AC, Guimarães PTG, Venegas-Alvarez VH. Recomendações para o uso de Corretivos e Fertilizantes em Minas Gerais (5 Aproximação). CSFSEMG/UFV, Viçosa, MG, 1999.

Rigal C, Xu J, Hu G, Qiu M, Vaast P. Coffee production during the transition period from monoculture to agroforestry systems in near optimal growing conditions, in Yunnan Province. Agricultural Systems, 2020; 177: 102696. https://doi.org/10.1016/j. agsy.2019.102696

Sánchez C, Caballero D, Cupull R, Gonzáles C, Urquiaga S, Rivera $\mathrm{R}$. Los abonos verdes y La inoculación micorrízica de plántulas de Coffea arabica sobre suelos cambisoles gléyicos. Cultivos Tropicales, 2009; 30: 25-30.

Santos R, Rodrigues L, Lima C, Jaramill-Botero C. Coffee Yield and Microenvironmental Factors in a Native Tree Agroforestry System in Southeast Minas Gerais, Brazil, Journal of Sustainable Agriculture, 2012; 36: 54-68. https://doi.org/10.1080/10440046.2011.608468

Schleppi P, Conedera M, Sedivy I, Thimonier A. Correcting nonlinearity and slope effects in the estimation of the leaf area index of forests from hemispherical photographs. Agric. For. Meteorol. 2007; 144: 236-242. https://doi.org/10.1016/j.agrformet.2007.02.004

Simon L, Lalonde M, Bruns TD. Specific amplification of 18 S fungal ribosomal genes from vesicular-arbuscular endomycorrhizal fungi colonizing roots. Appl Environ Microbiol. 1992; 58: 291-295. https://www. ncbi.nlm.nih.gov/pmc/articles/PMC195206/pdf/aem00042-0311.pdf

Siqueira JO, Saggin-Júnior OJ, Flores-Aylas WW, Guimarães PTG. Arbuscular mycorrhizal inoculation and superphosphate application influence plant development and yield of coffee in Brazil. Mycorrhiza 1998; 7:293-300. https://doi.org/10.1007/s005720050195

Smith SE, Smith FA. Roles of arbuscular mycorrhizas in plant nutrition and growth: new paradigms from cellular to ecosystem scales. Annu Ver. Plant Biol. 2011; 62: 227-250. https://doi: 10.1146/ annurev-arplant-042110-103846.

Steidinger BS, Croiwther TW, Liang J, Nuland MV. et al. Climatic controls of decomposition drive the global biogeography of forest tree symbioses. Nature. 2019; 569: 404-408. https://doi.org/10.1038/ s41586-019-1128-0

Veloso TGR, da Silva MCS, Cardoso WS. et al. Efeitos de fatores ambientais na microbiota de frutos e solo de Coffea arabica no Brasil. Sci Rep 2020; 10: 14692. https://doi.org/10.1038/s41598-020-71309-y

Viana, M.C.M., Silva, E.A., Queiroz, D.S., Paes, J.M.V., Albernaz, W.M., Fraga, G. Cultivo de macaúba em sistemas agrossilvipastoris. Inf. Agropecu. 2011; 32: 70-80.

Whitford KR, Colquhoun IJ, Lang ARG, Harper BM. Measuring leaf are index in a sparse eucalypt forest: a comparison of estimates from direct measurement, hemispherical photography, sunlight transmittance and allometric regression. Agric. For. Meteorol. 1995; 74: 237-249. https://doi.org/10.1016/0168-1923(94)02189-Q

Zhang J, Tang X, Zhong S, Yin G, Gao Y, He X. Recalcitrant carbon components in glomalin-related soil protein facilitate soil organic carbon preservation in tropical forests. Sci Rep. 2017; 7: 2391. https://doi.org/10.1038/s41598-017-02486-6 